\title{
PENERAPAN METODE STUDENT TEAM ACHIEVEMENT DIVISIONS (STAD) DALAM MENINGKATKAN AKTIVITAS BELAJAR SISWA PADA MATA PELAJARAN PENDIDIKAN AGAMA HINDU KELAS V DI SDN DAMPELAS
}

\author{
I Komang Mertayasa \\ I Ketut Suardika \\ Institut Agama Hindu Negeri Tampung Penyang Palangkaraya \\ Sekolah Tinggi Agama Hindu Dharma Sentana Sulawesi Tengah \\ Komang_mertayasa19@yahoo.com \\ Suardika@gmail.com
}

\begin{abstract}
Riwayat Jurnal
Artikel diterima $\quad: 8$ Juli 2019

Artikel direvisi $\quad: 25$ Juli 2019

Artikel disetujui : 1 Agustus 2019
\end{abstract}

\begin{abstract}
Abstrak
Pembelajaran yang kreatif tercipta apabila guru mampu untuk merubah paradigma pembelajaran menuju ke pembelajaran yang berorientasi kepada peserta didik (student centered learning). Proses pembelajaran Pendidikan Agama Hindu pada Sekolah Dasar yaitu SDN 15 Dampelas Kabupaten Donggala Provinsi Sulawesi Tengah situasi dalam kelas kurang kondusif dan suasana pembelajaran terlihat tidak efektif. Guru dalam menjelaskan materi masih menggunakan metode yang konvensional yaitu ceramah, dan sangat sedikit diselingi dengan pengajuan pertanyaan dan tdak mendapat respon maksimal dari siswa. Penerapan metode Student Team Achievement Divisions (STAD), akan dapat meningkatkan aktivitas belajar siswa. Berdasarkan pelaksanaan siklus I dan II diperoleh bahwa aktifitas guru meningkat dari $75 \%$ menjadi 95,83\%, sehingga pada siklus II sesuai dengan observasi yang dilakukan mengalami peningkatan sebesar 20,83\%. Sedangkan pencapaian aktivitas siswa pada saat mengikuti pembelajaran siklus I mencapai 63,64\%, meningkat menjadi 90,91\%. Peningkatan dari siklus I ke siklus II adalah sebesar 27,27\%. Pada siklus II aktivitas guru dan siswa berada dalam kriteria sangat baik dimana $75 \%<\mathrm{NR}$ $\leq 100 \%$. Oleh karena itu penerapan metode STAD dalam pembelajaran pendidikan agama Hindu khususnya materi catur guru dapat meningkatkan aktivitas belajar siswa kelas V SDN Dampelas

Kata Kunci:Student Team Achievement Divisions Aktivitas BelajarAgama Hindu
\end{abstract}

\section{Pendahuluan}

UU Nomor 20 Tahun 2003 tentang sistem Pendidikan Nasional mengamanatkan bahwa tujuan pendidikan adalah mengembangkan potensi peserta didik agar menjadi manusia yang beriman dan bertakwa kepada Tuhan Yang Maha Esa, berakhlak mulia, sehat, berilmu, 
cakap, kreatif, mandiri dan menjadi warga negara yang demokratis serta bertanggung jawab." Pendidikan bertujuan untuk mengembangkan potensi yang dimiliki oleh siswa. Setiap peserta didik memiliki bakat masing-masing yang patut untuk dikembangkan melalui pendidikan. Potensi peserta didik akan dapat berkembang jika guru sebagai manajer dalam kelas mampu untuk memahami bakat peserta didiknya. Bakatbakat tersebut akan dapat berkembangan melalui proses pembalajaran yang kreatif dan inovatif. Sardiman, (2005:96) mengatakan bahwa pada proses belajar mengajar tugas guru adalah mengembangkan dan menyediakan kondisi agar peserta didik dapat mengembangkan bakat dan potensinya.

Guru yang sukses bukan sekedar penyaji yang kharismatik dan persuasive, lebih jauh adalah mereka yang melibatkan para siswa dalam tugas-tugas yang sarat muatan kognitif dan sosial serta mengajari mereka bagaimana cara mengerjakan tugas tersebut secara produktif (Calhoun, dkk, 2011: 7). Penguasaan dan kemampuan guru dalam memilih serta menerapkan model pembelajaran yang sesuai menjadi point penting dalam membuat suasana pembelajaran yang efektif. Kekeliruan dalam memilih dan menerapkan metode mengajar akan berdampak pada kurangnya motivasi belajar siswa sehingga berdampak pula pada pencapaian tujuan pembelajaran. Motivasi memberikan pengaruh yang besar untuk menjaga kelangsungan belajar siswa dalam tingkat kesungguhan belajar siswa yang tinggi (Suardi, 2012: 118).

Model harus dipahami sebagai kerangka konseptual yang mendeskripsikan dan melukiskan prosedur yang sistematik dalam belajar tertentu, dan berfungsi sebagai pedoman bagi para guru dalam melaksanakan aktivitas pembelajaran. Pembelajaran yang kreatif tercipta apabila guru mampu untuk merubah paradigma pembelajaran menuju ke pembelajaran yang berorientasi kepada peserta didik (student centered learning). Guru tidak lagi mendominasi dalam pembelajaran di kelas, guru berfungsi sebagai fasilitator dan motivator dalam proses pembelajaran. Guru bertugas memberikan motivasi dalam pembelajaran sehingga siswa menjadi memiliki semangat dalam belajar. Winkel (2012: 186) menyatakan bahwa motivasi merupakan motor penggerak yang mengaktifkan siswa untuk melibatkan diri. Peserta didik akan merasa senang dan tertarik untuk belajar apabila guru mampu membuat suasana kelas meyenangkan, bukan menegangkan.

Secara umum proses pembelajaran Pendidikan Agama Hindu pada salah satu Sekolah Dasar yaitu SDN 15 Dampelas Kabupaten Donggala Provinsi Sulawesi Tengah khususnya pada kelas V, situasi dalam kelas kurang kondusif dan suasana pembelajaran terlihat tidak efektif. Guru menjelaskan kurang diperhatikan oleh peserta didik, karena pada saat proses pembelajaran beberapa siswa terlihat sibuk sendiri dengan temannya dan tidak 
memperhatikan ketika pemaparan materi. Suardi (2012: 118) mengungkapkan bahwa rendahnya motivasi belajar dapat dilihat dari sikap siswa yang kurang bergairah serta kurang bersemangat dalam belajar sehingga suasana belajar menjadi kurang aktif, interaksi antara guru dan siswa sangat kurang apalagi siswa dengan siswa.

Rendahnya motivasi belajar siswa disebabkan oleh cara guru dalam menjelaskan materi masih menggunakan metode yang konvensional yaitu ceramah, dan sangat sedikit diselingi dengan pengajuan pertanyaan dan tidak mendapat respon maksimal dari siswa. Penggunaan tanya jawab menjadikan siswa akan merasa terlibat langsung dalam proses pembelajaran sehingga mereka termotivasi selama pembelajaran berlangsung (Suardi, 2012: 118). Bertanya dapat dikatakan merupakan cara paling efektif bagi guru untuk melibatkan murid dan guru terlepas dari model mengajar yang digunakan (Kauchak dan Paul, (2012: 6).

Pembelajaran kurang menarik sehingga siswa pasif dan tidak terjadi interaksi yang edukatif antara siswa dengan guru dan antar siswa dengan teman-temannya. Ketika proses belajar mengajar berlangsung, hanya beberapa kali saja siswa mengajukan pertanyaan, dan yang bertanya hanya beberapa orang saja secara berulang dari beberapa kali pertemuan. Hal ini mengindikasikan bahwa hanya beberapa orang saja yang memperhatikan ketika proses pembelajaran. Selain siswa diberikan kesempatan untuk bertanya, sesekali guru juga mengajukan pertanyaan kepada siswa terkait materi yang diberikan, akan tetapi jarang siswa yang menjawab pertanyaan dengan mengancungkan tangan. Siswa sebagian besar saling berbisik dengan temannya, dan tidak memiliki keberanian untuk mengungkapkan jawabannya secara mandiri.

Beberapa hal di atas mengindikasikan bahwa siswa kurang memiliki kepercayaan diri dalam mengungkapkan pendapatnya dan memiliki kencenderungan memilih diam ketika terdapat materi yang belum dipahami, kurang aktif dalam menanyakan hal yang tidak dipahami. Aktivitas belajar siswa pada pembelajaran Pendidikan Agama Hindu dalam kondisi di atas nampak rendah, sehingga perlu dilakukan inovasi-inovasi dalam penerapan model maupun metode pembelajaran. Guru dapat mengambil berbagai tindakan instruksional untuk meningkatkan motivasi belajar siswa. Mengusahakan agar siswa menaruh kepercayaan pada diri sendiri, belajar dengan semangat serta rasa antusias, (Winkel, 2012: 193). Diperlukan modelmodel mengajar yang dipandang mampu mengatasi kesulitan guru melaksanakan tugas mengajar dan juga kesulitan belajar peserta didik. Calhoun dkk (2011: 7) cara penerapan suatu pembelajaran akan berpengaruh besar terhadap kemampuan siswa dalam mendidik diri mereka sendiri. 
$\begin{array}{rcr}\text { Model } & \begin{array}{c}\text { Pembelajaran } \\ \text { (Cooperative }\end{array} \text { Learning } & \text { Models) }\end{array}$ merupakan suatu cara untuk mengatasi berbagai problematika dalam pelaksanaan pembelajaran. Pembelajaran kooperatif merupakan pembelajaran yang dibentuk dalam suatu kelompok kecil dimana siswa bekerja sama dan mengoptimalkan keterlibatan dirinya dan anggota kelompoknya dalam belajar. Hamdani (2011: 30) mengungkapkan dalam pembelajaran kooperatif diterapkan strategi belajar dengan sejumlah siswa sebagai anggota kelompok kecil yang tingkat kemampuannya berbeda. Menyelesaikan tugas dengan saling bekerjasama dan saling membantu untuk memahami materi pelajaran. Pembelajaran belum selesai jika salah satu teman dalam kelompok belum menguasai bahan pelajaran.

$$
\text { Dalam belajar kooperatif }
$$

(Cooperative Learning), siswa diberikan dua macam tanggung jawab yang harus dilaksanakan. Pertama, semua siswa terlibat dalam mempelajari dan menyelesaikan materi/tugas yang diberikan oleh guru. Kedua, meyakinkan bahwa semua anggota dalam kelompok mengerti dan memahami tentang materi/tugas yang diterimanya. Dengan demikian siswa dapat menyadari bahwa hasil yang diperoleh mempunyai manfaat bagi diri dan siswa lainnya dalam kelompok tersebut, (Sagala, 2004:175).

Trianto

mengungkapkan bahwa dalam pembelajaran kooperatif (Cooperative Learning), siswa saling membantu untuk memahami suatu materi pelajaran, memeriksa dan memperbaiki jawaban temannya yang salah, serta aktivitas lainnya dengan tujuan untuk mencapai prestasi belajar yang tinggi. Pembelajaran kooperatif disusun dalam sebuah usaha untuk meningkatkan partisipasi siswa, memfasilitasi siswa dengan pengalaman sikap kepemimpinan dan membuat keputusan dalam kelompok, serta memberikan kesempatan pada siswa untuk berinteraksi dan belajar bersamasama siswa yang berbeda latar belakangnya. Slavin (1995) mengungkapkan pembelajaran kooperatif terdiri dari para siswa bekerja sama di dalam kelompok-kelompok cukup kecil (biasanya dua hingga lima) yang bisa diikuti semua orang di dalam tugas yang jelas (Kaunchak dan paul, 2012: 128129).

\section{Pembelajaran Kooperatif} (Cooperative Learning) dilakukan dengan membuat siswa untuk berinteraksi dengan teman kelompoknya dalam menyelesaikan tugas atau materi yang diberikan oleh guru. Uno (2006: 2) siswa tidak hanya berinteraksi dengan guru sebagai salah satu sumber belajar, tetap mungkin berinteraksi dengan keseluruhan sumber belajar yang dipakai untuk mencapai tujuan pembelajaran yang diinginkan. Oleh karena itu dalam pembelajaran selain terjadi interaksi dengan guru juga terjadi dengan sumber lain. Peserta didik juga merupakan sumber belajar bagi peserta didik lainnya, karena akan ada pengetahuan yang di peroleh saat berinteraksi dengan sesama 
peserta didik. Interaksi tersebut berlahan akan membelajarkan siswa untuk terbiasa melakukan komunikasi. Bermula dari komunikasi dengan teman sekelompok, berlahan mengarah pada munculnya keberanian untuk berkomunikasi dengan teman yang berbeda kelompok dan akhirnya berkomunikasi dengan gurunya. Hal tersebut akan dapat meningkatkan aktivitas belajar siswa di dalam kelas yang pada akhirnya juga akan berdampak pada perolehan prestasi belajar siswa.

Saat siswa bekerja sama dalam kelompok akan mendapatkan pengalaman yang dapat mendorong sejumlah keterampilan sosial yaitu (1). Menyimak dengan penuh perhatian; (2). Membaca petunjuk-petunjuk nonverbal; (3). Menyelesaikan ketidaksepahaman (secara diplomatis); (4). Mencurahkan pikiran ke dalam kata-kata; (5). Memahami sudut pandang orang lain; (6). Membuat pernyataan mendukung; (7). Memberikan pujian tulus, (Kauchak dan Paul, 2012: 130).

Pembelajaran Kooperatif tipe Student Team Achievement Divisions (STAD) merupakan model pembeajaran kooperatif yang menempatkan siswa dalam tim belajar beranggotakan empat orang yang merupakan empat campuran menurut tingkat kinerjanya jenis kelamin dan suku. Hamdani (2011: 35) Siswa dalam kelas dibagi menjadi kelompok dengan jumlah anggota 4-5 orang. Kelompok harus heterogen terdiri atas perempuan dan laki-laki, berbagai suku, memiliki kemampuan tinggi sedang dan rendah. Penerapan metode ini diharapkan siswa lebih kreatif dalam belajar, untu dapat memupuk rasa kerja sama, dan memiliki rasa tanggung jawab yang tinggi. Slavin (1986) Student Team Achievement Divisions (STAD) sebuah strategi pembelajaran kooperatif yang memberi tim berkemampuan majemuk untuk latihan mempelajari konsep dan keahlian bersama para siswa (Kauchak dan Paul, 2012: 144). Penggunakan metode Student Team Achievement Divisions (STAD) diharapkan siswa mengembangkan kerja tim, keterampilan belajar kooperatif dan menguasai pengetahuan secara mendalam yang tidak mungkin diperoleh apabila mereka mencoba untuk mempelajari semua materi sendirian, sehingga diperlukan adanya diskusi kelompok. Siberman (2013: 30) menempatkan siswa dalam kelompok dan memberi tugas yang menuntut mereka untuk bergantung satu sama yang lain dalam mengerjakan tugas merupakan cara yang bagus untuk memanfaatkan kebutuhan sosial siswa

Pembelajaran pendidikan agama Hindu, layaknya mata pelajaran lainnya membutuhkan situasi belajar yang menenyenangkan dan kreatifitas dari para pendidik, sehingga tujuan pembelajaran baik kognitif, afektif maupun psikomotorik dapat tercapai. Penerapan model pembelajaran kooperatif tipe Student Team Achievement Divisions (STAD) diharapkan mampu untuk meningkatkan aktivitas belajar siswa pada mata pelajaran pendidikan agama Hindu.

\section{Metode}


Jenis penelitian yang digunakan yaitu Penelitian Tindakan Kelas (PTK). Somadayo (2013: 20) menyatakan bahwa hakekat penelitian tindakan kelas merupakan ragam penelitian pembelajaran yang berkonteks kelas yang dilaksanakan oleh guru untuk memecahkan masalah-masalah pembelajaran yang di hadapi, memperbaiki mutu dan hasil pembelajaran dan mencobakan hal-hal baru pembelajaran demi peningkatan mutu dan hasil pembelajaran. PTK merupakan salah satu alternatif tindakan yang dilakukan dalam konteks pebelajaran di kelas dan bertujuan untuk memperbaiki praktek pembelajaran di kelas sehingga mampu meningkatkan aktivitas belajar siswa dan menjadikan siswa lebih kreatif serta mampu mengenali bakatnya sendiri. Hal tersebut sangat penting bagi siswa karena dalam pembelajaran di kelas guru hanya sebagai fasilitator dalam pengembangan bakat dan potensi yang dimiliki oleh peserta didik.

Rancangan penelitian tindakan kelas mengacu pada diagram Model Kemmis dan Mc Taggart dalam Rofi'udin (1996) merupakan model pengembangan dari model Kurt Lewin. Dikatakan demikian, karena di dalam suatu siklus terdiri atas empat komponen, keempat komponen tersebut, meliputi: (1) perencanaan, (2) aksi/tindakan, observasi, dan (4) refleksi. Seperti terlihat di bawah ini:

Gambar 1. Desain PTK Menurut Kemmis dan Taggart

\begin{tabular}{|c|c|}
\hline$\frac{2}{8}$ & $\begin{array}{l}\text { Keterangan: } \\
\text { 0. Observasi } \\
\text { 1. Rencana siklus } 1 \\
\text { 2. Pelaksanaan siklus } 1 \\
\text { 3. Observasi siklus } 1 \\
\text { 4. Refleksi siklus } 1 \\
\text { 5. Rencana siklus } 2 \\
\text { 6. Pelaksanaan siklus } 2 \\
\text { 7. Observasi siklus } 2 \\
\text { 8. Refleksi siklus } 2 \\
\text { a. siklus I } \\
\text { b. Siklus II }\end{array}$ \\
\hline
\end{tabular}

Sumber : Adopsi dari model Kemmis dan Taggart dalam Susilo, dkk (2012: 12)

Objek dalam penelitian ini meliputi aktivitas belajar siswa pada materi pendidikan agama hindu. Aktivitas belajar yang dimaksud bersifat fisik maupun mental dalam proses kegiatan pembelajaran guna menunjang keberhasilan proses belajar mengajar pada setiap akhir siklus pembelajaran.

Jenis data penelitian ini adalah data kualitatif dan data kuantitatif. Data kualitatif yaitu data yang diambil dengan cara menggunakan wawancara aktivitas 
siswa dalam bentuk diskripsi (sifat). Sedangkan data kuantitatif yaitu data yang diambil dengan menggunakan lembar observasi aktivitas belajar siswa, berupa angka-angka atau nilai-nilai.

Metode pengumpulan data yang digunakan dalam penelitian ini adalah observasi dan wawancara. Teknik observasi yaitu data yang diambil dengan menggunakan lembar obvervasi aktivitas guru dan siswa. Pengamatan dalam pengertian ini adalah pengamatan pada saat berlangsungnya fenomena-fenomena yang terjadi di kelas saat proses pembelajaran berlangsung. Wawancara (Interview)adalah cara-cara memperoleh data dengan berhadapan langsung, bercakap-cakap, baik antara individu dengan individu maupun individu dengan kelompok. Wawancara dilakukan untuk menelusuri kesulitan-kesulitan yang dialami siswa dalam sebab-sebab permasalahan yang menjadi kesulitan siswa dalam mengikuti pembelajaran.

Teknik analisis data yang digunakan dalam penelitian ini yaitu teknik analisis data kualitatif dan kuantitatif. Analisis data kualitatif ini dilakukan yaitu dengan: (1) reduksi data,
(2) penyajian data, dan (3) kesimpulan. Milles dan Huberman (1992:137). Reduksi data yaitu Data-data dipilih sesuai hal-hal pokok dalam membahas permasalahan, sehingga memudahkan peneliti dalam pengumpulan data. Penyajian Data yaitu menyusun data secara sederhana kedalam tabel dan diberi nama data kulitatif. Sehingga meberikan kemungkinan adanya penarikan kesimpulan. Kesimpulan yaitu berdasarkan data yang telah dikemukakan dan disajikan dengan terstruktur maka data-data dapat dianalisis untuk menarik sebuah kesimpulan. Penarikan kesimpulan merupakan pengungkapan akhir dari hasil tindakan.

Analisis data kuantitatif yaitu data aktivitas guru dan aktivitas belajar siswa menggunakan analisis persentase skor rata-rata. Untuk indikator sangat baik diberi 4 , baik diberi 3 , cukup diberi 2 dan kurang baik diberi 1 . Kemudian yang diperoleh melalui lembar hasil observasi kemudian dianalisis dan dinyatakan dalam bentuk persentase yang dihitung dengan menggunakan rumus:

Persentase nilai rata-rata $(\mathrm{NR})=\frac{\text { skor perolehan }}{\text { skor } \text { maksimal }} \times 100 \%$

Tabel 1. Kriteria Keberhasilan Aktivitas Guru dan Siswa

\begin{tabular}{c|c}
\hline Nilai rata-rata (NR) & Keterangan \\
\hline $75 \%<\mathrm{NR} \leq 100 \%$ & $\mathrm{~A}=$ Sangat Tinggi \\
\hline $50 \%<\mathrm{NR} \leq 75 \%$ & $\mathrm{~B}=$ Baik \\
\hline $25 \%<\mathrm{NR} \leq 50 \%$ & $\mathrm{C}=$ Sedang / cukup \\
\hline $1 \%<\mathrm{NR} \leq 25 \%$ & $\mathrm{D}=$ Rendah \\
\hline
\end{tabular}

Sumber : Purwanto (2010) 
Kriteria taraf keberhasilan tindakan, apabila skor rata-rata lebih besar dari $75 \%$ dan kurang dari atau sama dengan $100 \%$ maka dikategorikan sangat baik, apabila skor rata-rata lebih dari $50 \%$ dan kurang dari sama dengan $75 \%$ dikategorikan baik, apabila skor rata-rata lebih besar dari $25 \%$ dan kurang dari sama dengan 50\% dikategorikan cukup, serta apabila skor rata-rata lebih besar dari $1 \%$ dan kurang dari sama dengan 25\% maka dikategorikan kurang baik. Jadi yang dinyatakan tuntas dalam hasil observasi yang baik terhadap guru maupun siswa adalah yang mencapai kategori baik $(50 \%<\mathrm{NR} \geq 75 \%$ Baik).

Pelaksanaan penelitian dilaksanakan dalam dua siklus yang terdiri dari 4 tahap yaitu 1) Perencanaan tindakan, 2) Pelaksanaan tindakan, 3) Observasi, dan 4) Refleksi.

Perencanaan tindakan yaitu kegiatan untuk membuat rencana pembelajaran, menyiapkan alat bantu pembelajaran, membuat lembaran kerja siswa, membuat lembar observasi sebagai alat pengumpul data untuk mengetahui bagaimana aktivitas belajar mengajar di kelas pada waktu berlangsungnya kegiatan pembelajaran baik siswa atau guru. Pelaksanaan Tindakan yaitu melaksanakan kegiatan belajar mengajar dengan pembelajaran Koopertif tipe STAD, pemberian tes siklus I, membuat dokumentasi kegiatan belajar mengajar. Observasi yaitu kegiatan mengamati dan mencatat proses yang terjadi selama pembelajaran siklus I pada aktivitas guru (peneliti) dan siswa. Observasi dilakukan oleh observer (guru). Refleksi yaitu menganalisis data yang diperoleh pada tahap observasi. Berdasarkan hasil yang didapatkan, guru akan mereflesikan identifikasi kelebihan dan kekurangan dari hasil pengamatan untuk dilakukan perbaikan-perbaikan dari tindakan tersebut.

Berdasarkan hasil analisis tindakan yang dilaksanakan pada siklus I, dilakukan perbaikan pelaksanaan pembelajaran yakni dengan penerapan model pembelajaran kooperatif metode STAD pada siklus II. Pelaksanaan siklus II disesuikan dengan perubahan yang ingin dicapai seperti apa yang telah didesain dalam konsep yang diteliti. Kemudian hasil yang diperoleh pada siklus ini dikumpulkan dan dianalisis untuk menetapkan suatu kesimpulan apabila indikator telah terpenuhi. Apabila indikator belum terpenuhi, maka tidak akan dilanjutkan pada siklus berikutnya dan dianggap metode STAD tidak tepat digunakan untuk mengajar pada materi tersebut, sehingga hipotesis tindakan tidak diterima.

\section{Pembahasan}

\section{Pelaksanaan Tindakan Siklus I}

Kegiatan siklus satu dilaksanakan dua kali pertemuan satu kali tatap muka dan satu kali tes akhir siklus I kegiatan ini berlangsung di kelas $\mathrm{V}$ dan diikuti 20 siswa. Pertemuan pertama dilaksanakan pada standar kompetensi mengenal ajaran Catur Guru kompetensi dasar menyebutkan bagian-bagian Catur Guru. Pertemuan kedua dilakukan dengan 
memberikan tes kepada siswa. Pelaksanaan kegiatan pembelajaran dilakukan dengan tiga tahapan yaitu tahap pendahuluan, kegiatan inti dan kegiatan penutup.

\section{Pendahuluan}

Kegiatan awal dalam pelaksanaan tindakan ini dimulai dengan pembukaan yang meliputi penyampaian salam panganjali, mengabsen siswa, memotivasi siswa dan menyampaikan tujuan pembelajaran yang dicapai.

2. Kegiatan inti

Kegiatan inti diawali dengan guru membentuk lima kelompok belajar, masing-masing kelompok beranggotakan empat orang yang bersifat hetorogen, berdasarkan hasil tes awal yang dilakukan.

a. Menyampaikan materi pembelajaran secara singkat dan jelas di dalam proses pembelajaran guru dibantu dengan media gambar.

b. Membagikan LKS kepada setiap kelompok dan memberikan masalah yang pernah dialami dalam kehidupan sehari-hasi siswa. c. Guru memantau/membimbing setiap kelompok untuk bisa bekerjasama dalam kelompoknya.

$d$. Guru mengevaluasi hasil belajar melalui pemberian kuis.

e. Guru memberikan penghargaan untuk menghargai hasil perkerjaan baik secara kelompok maupun individu.

\section{Kegiatan penutup}

Pada kegiatan penutup, guru membimbing siswa untuk menyimpulkan materi yang dibahas, memberikan kesempatan kepada siswa untuk bertanya kemudian setelah itu guru dan siswa mengakhiri proses pembelajaran dengan salam paramasanti. Selama proses pembelajaran berlangsung, dilakukan observasi aktivitas guru dan siswa.

\section{Hasil Tindakan Siklus I}

Penilaian Aktivitas Guru

Dalam kegiatan ini, untuk mengetahui aktivitas guru saat proses pembelajaran dapat dengan jelas gambaran tentang kemamapuan guru pada saat melaksanakan proses pembelajaran siklus I. Adapun hasil aktivitas guru dapat dilihat pada tabel berikut.

Tabel 2. Hasil Observasi Aktivitas Guru Siklus I

\begin{tabular}{c|c}
\hline Hasil Observasi Aktivitas Guru & Jumlah Skor \\
\hline Jumlah skor diperoleh & 36 \\
\hline Skor maksimal & 48 \\
\hline Aktivitas Guru (\%) & 75 \\
\hline
\end{tabular}

Sumber : Diolah dari Lembar Observasi Aktivitas Guru

Berdasarkan tabel 2. diperoleh bahwa aktivitas guru dalam dalam pembelajaran dengan menerapkan metode STAD termasuk kedalam kategori baik 
dengan persentase $75 \%$. Masih perlu dilakukan beberapa perbaikan oleh guru dalam penerapan metode STAD sehingga nantinya memperoleh aktivitas belajar siswa yang lebih maksimal. Guru perlu untuk meminimalkan kekurangan yang terdapat pada siklus I seperti guru masih kurang dalam menyampaikan materi secara jelas dan mudah dimengerti oleh siswa, memberi kesempatan kepada siswa untuk bertanya serta dalam hal menyimpulkan materi pembelajaran.

Pembelajaran siklus I terdapat beberapa kelemahan yang terjadi dalam prosesnya, kelemahan-kelemahan tersebut sebagaimana juga diungkapkan oleh beberapa siswa yang diwawancarai. Hasil wawancara dengan siswa yaitu KJ (Klp II) menyatakan bahwa guru dalam memberikan penjelasan terlalu cepat menjadi sulit dipahami. Selanjutnya NM (klp IV) menyatakan bahwa contoh yang diberikan guru kepada siswa belum pernah kami alami, jadi kami tidak terlalu mengerti. Kauchak dan Paul (2012: 54) Belajar meningkat saat pengalaman belajar dikaitkan dengan dunia nyata.

Kutipan wawancara tersebut mengungkapkan bahwa dalam pelaksanaan pembelajaran guru memliki kelemahan pada menjelaskan materi yang terlalu cepat dan pemberian contoh yang masih agak sulit di pahami siswa, oleh karena itu hal tersebut menjadi perhatian bagi guru dalam pelaksanaan siklus II. Hasil wawancara dengan HS (Klp V) mengungkapkan bahwa diakhir bagian pembelajaran guru terlalu terburu-buru, dan menyimpulkan sendiri. Dari ungkapan tersebut sehingga dapat disimpulkan bahwa dalam kegiatan penutup dalam pembelajaran guru kurang maksimal dan tidak memberikan kesempatan kepada siswa untuk ikut serta dalam menyimpulkan materi yang telah di bahas pada pertemuan tersebut.

\section{Refleksi}

Berdasarkan hasil pelaksanaan tindakan siklus I selama kegiatan belajar mengajar berlangsung setelah dilakukan refleksi, diperoleh beberapa kelemahan yang nantinya dapat dijadikan pertimbangan dalam pelaksanaan siklus II. Adapun permasalahan-permasalahan tersebut dimuat dalam tabel berikut.

Tabel 3. Kelemahan, Penyebab dan Solusi Analisis Siklus I Pada Aktivitas Guru

\begin{tabular}{|c|c|c|c|c|}
\hline No & Tindakan & Kelemahan & Penyebab & Solusi \\
\hline 1 & $\begin{array}{l}\text { Presentasi } \\
\text { Materi }\end{array}$ & $\begin{array}{lr}\text { Menyampaikan } & \text { materi } \\
\text { pembelajaran } & \text { secara } \\
\text { singkat dan } & \text { jelas. } \\
\text { Didalam } & \text { proses } \\
\text { pembelajaran guru } \\
\text { dibantu oleh media, } \\
\text { LKS, demonstrasi, }\end{array}$ & $\begin{array}{l}\text { Siswa tidak mau } \\
\text { bertanya karena } \\
\text { siswa malu untuk } \\
\text { bertanya }\end{array}$ & $\begin{array}{l}\text { Guru } \\
\text { memberikan } \\
\text { arahan dan } \\
\text { memberikan } \\
\text { penghargaan } \\
\text { kepada yang } \\
\text { bertanya. }\end{array}$ \\
\hline
\end{tabular}




\begin{tabular}{l|l|l|l|l}
\hline & & $\begin{array}{l}\text { pertanyaan atau masalah } \\
\text { nyata yang terjadi dalam } \\
\text { kehidupan sehari-hari }\end{array}$ & & \\
\hline 2 & $\begin{array}{l}\text { Pembelajaran } \\
\text { Kelompok }\end{array}$ & $\begin{array}{l}\text { Memantau/membimbing } \\
\text { setiap kelompok untuk } \\
\text { bisa berkerjasama dalam } \\
\text { kelompoknya }\end{array}$ & $\begin{array}{l}\text { Guru belum dapat } \\
\text { membimbing } \\
\text { pembelajaran } \\
\text { semua kelompok }\end{array}$ & $\begin{array}{l}\text { Melakukan } \\
\text { bimbingan } \\
\text { kelompok } \\
\text { secara adil }\end{array}$ \\
\hline 3 & Refleksi & $\begin{array}{l}\text { Terdapat dalam } \\
\text { bagian tiak } \\
\text { kesimpulan yang tidak } \\
\text { mengarah pada tujuan } \\
\text { pembelajaran. }\end{array}$ & $\begin{array}{l}\text { Guru } \\
\text { menyimpulkan } \\
\text { tidak } \\
\text { memfokuskan } \\
\text { perhatian pada } \\
\text { tujuan } \\
\text { pembelajaran }\end{array}$ & $\begin{array}{l}\text { Mengimpulkan } \\
\text { dengangan } \\
\text { yang } \\
\text { sederhana dan } \\
\text { menyesuaikan } \\
\text { dengan tujuan } \\
\text { pembelajaran }\end{array}$ \\
\hline 4 & Penutup & $\begin{array}{l}\text { Memberikan kesempatan } \\
\text { kepada siswa untuk } \\
\text { bertanya }\end{array}$ & $\begin{array}{l}\text { Waktu } \\
\text { pembelajaran } \\
\text { yang } \\
\text { efektif }\end{array}$ & $\begin{array}{l}\text { Lebih } \\
\text { memperhitung } \\
\text { kan } \\
\text { penggunaan } \\
\text { waktu dalam } \\
\text { pembelajaran }\end{array}$ \\
\hline
\end{tabular}

Sumber: diolah dari hasil observasi aktivitas guru dan wawancara siklus I

Penilaian Aktivitas Siswa

$\begin{array}{ccr}\text { Observasi } & \text { aktivitas } & \text { siswa } \\ \text { dilakukan pada } & \text { saat kegiatan }\end{array}$

pembelajaran berlangsung dengan penerapan metode STAD pada siklus I dapat dilihat pada tabel berikut:

Tabel 4. Hasil Observasi Aktivitas Siswa Siklus I

\begin{tabular}{c|c}
\hline Hasil Observasi Aktivitas Siswa & Jumlah Skor \\
\hline Skor Perolehan & 28 \\
\hline Skor Maksimal & 44 \\
\hline Aktivitas Siswa (\%) & 63,64 \\
\hline
\end{tabular}

Sumber : Diolah dari Lembar hasil observasi Aktivitas Siswa Siklus I

Berdasarkan tabel di atas, jumlah skor perolehan adalah sebesar 28 dan jumlah skor maksimal yaitu 44. Besar aktivitas belajar siswa sesuai dengan lembar observasi yang telah di isi oleh observer persentase aktivas siswa pada siklus I sebesar 63, $64 \%$. Jumlah tersebut berada dalam kriteria baik dan dapat dinyatakan tuntas karena hasil observasi yang baik terhadap guru maupun siswa 
adalah yang mencapai kategori baik (50\% $<\mathrm{NR} \geq 75 \%$ Baik), akan tetapi pencapaian tersebut perlu ditingkatkan karena dalam pelaksanaanya masih ada beberapa bagian yang belum maksimal dilaksanakan oleh guru.

Dari pelaksan pembelajaran pada siklus I dan setelah dilakukan refleksi tentang aktifitas siswa diperoleh beberapa kelemahan, yang dapat dijadikan perhatian oleh guru dalam pembelajaran siklus II. Adapun kelemahan-kelemahan

Tabel 5. Kelemahan, Penyebab dan Solusi Analisis Siklus I Pada Aktivitas Siswa

\begin{tabular}{|c|c|c|c|}
\hline No & Kelemahan & Penyebab & Solusi \\
\hline 1 & $\begin{array}{lr}\text { Siswa } & \text { kurang } \\
\text { menjawab } & \\
\text { pertanyaan yang } & \text { diberikan oleh guru }\end{array}$ & $\begin{array}{l}\text { Siswa tidak mau menjawab } \\
\text { karena siswa takut salah } \\
\text { dalam menjawab pertanyaan } \\
\text { yang diberikan oleh guru }\end{array}$ & $\begin{array}{l}\text { Memberikan motivasi } \\
\text { dan pemahaman } \\
\text { bahwa menjawab } \\
\text { salah tidak akan } \\
\text { mendapat sangsi }\end{array}$ \\
\hline 2 & $\begin{array}{lr}\text { Menyimak } & \text { tujuan } \\
\text { pembelajaran } & \text { yang } \\
\text { disampaikan } & \text { oleh } \\
\text { guru } & \end{array}$ & $\begin{array}{l}\text { Siswa cenderung tidak mau } \\
\text { memperhatikan guru dalam } \\
\text { menyampaikan } \\
\text { pembelajaran }\end{array}$ & $\begin{array}{l}\text { Guru memberikan } \\
\text { penekanan dalam } \\
\text { menyampaikan tujuan } \\
\text { pembelajaran }\end{array}$ \\
\hline 3 & \begin{tabular}{ll}
\multicolumn{2}{l}{ Mendengarkan } \\
penjelasan & guru \\
tentang materi & yang \\
telah diajarkan &
\end{tabular} & $\begin{array}{l}\text { Siswa segan untuk } \\
\text { menanyakan materi-materi } \\
\text { yang belum dipahami }\end{array}$ & $\begin{array}{l}\text { Guru menyelingi } \\
\text { pembelajaran dengan } \\
\text { humor yang relevan }\end{array}$ \\
\hline 4 & $\begin{array}{lr}\text { Ada } & \text { beberapa } \\
\text { yang kiswa } \\
\text { dan tidak mau } \\
\text { berkerja sama dalam } \\
\text { kelompok }\end{array}$ & $\begin{array}{l}\text { Karena adanya siswa tidak } \\
\text { mau nilainya sama dengan } \\
\text { siswa lainya }\end{array}$ & $\begin{array}{lr}\text { Guru menyampaikan } \\
\text { bahwa } r \text { terdapat } \\
\text { penilaian kelompok } \\
\text { dan penghargaan } \\
\text { kelompok }\end{array}$ \\
\hline 5 & $\begin{array}{ll}\text { Mendengarkan } & \\
\text { penjelasan } & \text { guru } \\
\text { tentang materi yang } \\
\text { telah diajarkan }\end{array}$ & $\begin{array}{lr}\text { Siswa } & \text { kurang } \\
\text { memperhatikan penjelasan } \\
\text { guru, sehingga kurang } \\
\text { memahami materi yang } \\
\text { dijelaskan oleh guru }\end{array}$ & $\begin{array}{l}\text { Menyampaikan } \\
\text { dengan tegas sangsi } \\
\text { yang akan diberikan } \\
\text { apabila tidak } \\
\text { memperhatikan saat } \\
\text { guru menjelaskan }\end{array}$ \\
\hline 6 & Menyimpulkan & Siswa tidak berani untuk & menunjuk \\
\hline
\end{tabular}




\begin{tabular}{l|l|l|l}
\hline & $\begin{array}{l}\text { materi siswa tidak } \\
\text { mau terlibat }\end{array}$ & $\begin{array}{l}\text { mengemukakan pendapatnya } \\
\text { sendiri }\end{array}$ & $\begin{array}{l}\text { beberapa siswa dalam } \\
\text { menyimpulkan materi }\end{array}$ \\
\hline
\end{tabular}

Sumber: diolah dari hasil observasi aktivitas siswa dan wawancara siklus I

\section{Pelaksanaan Tindakan Siklus II}

Pelaksanaan tindakan siklus II dilaksanakan sebanyak dua kali pertemuan satu kali kegiatan belajar mengajar dengan standar kompetensi menguraikan ajaran Catur Guru dan satu kali pertemuan untuk melaksanakan evaluasi. Kegiatan pembelajaran dilakukan sama mulai dari pendahuluan, kegiatan inti dan kegiatan penutup. Tahapan pelaksanaan tidak memiliki perbedaan dengan pelaksanaan siklus I. Guru hanya menambahkan beberapa poin sesuai dengan hasil refleksi yang dilakukan pada siklus I.

\section{Hasil Tindakan Siklus II}

\section{Hasil Observasi Aktivitas Guru}

Aktivitas guru saat proses pembelajaran pada siklus II, diperoleh hasil sebagaimana tertuang dalam tabel berikut.

Tabel 6. Hasil Observasi Aktivitas Guru Siklus II

\begin{tabular}{c|c}
\hline Hasil Observasi Aktivitas Guru & Jumlah \\
\hline Skor Perolehan & 46 \\
\hline Skor Maksimal & 48 \\
\hline Aktivitas Guru (\%) & $95,83 \%$ \\
\hline
\end{tabular}

Sumber : Diolah dari Lembar Aktivitas Guru Siklus II

Berdasarkan tabel 5 perolehan persentase aktivitas guru pada siklus II adalah $95,83 \%$. Nilai tersebut menunjukkan tingkat kinerja guru dikatagorikan sangat baik $(75 \%<\mathrm{NR} \leq$ $100 \%)$. Beberapa aspek yang mengalami kendala sudah diperbaiki yaitu dalam menyampaikan tujuan yang dicapai, kegiatan inti, dan penutup. Kriteria keberhasilan aktivitas guru dalam menerapkan metode STAD sudah dapat dikategorikan maksimal, karena berada pada taraf sangat baik. Memperhatikan hasil dari aktivitas yang dilakukan guru dalam pembelajaran pendidikan agama hindu dengan menerapkan metode STAD maka tidak perlu lagi dilakukan siklus II, karena angka tersebut sudah sangat mendekati kesempurnaan.

\section{Penilaian Aktivitas Siswa}

Observasi aktivitas siswa dilakukan pada saat kegiatan pembelajaran berlangsung dengan penerapan metode STAD siklus II dapat dilihat pada tabel berikut. 
Tabel 7. Hasil Observasi Aktivitas Siswa Siklus II

\begin{tabular}{c|c}
\hline Hasil Observasi Aktivitas Siswa & Jumlah \\
\hline Skor Perolehan & 40 \\
\hline Skor Maksimal & 44 \\
\hline Aktivitas Siswa (\%) & 90,91 \\
\hline
\end{tabular}

Sumber : Diolah dari lembar observasi Aktivitas Siswa Siklus II

Berdasarkan tabel di atas penilaianaktivitas siswa berdasarkan skala penilaian dapat diketahui adanya peningkatan aktivitas siswa menjadi $90,91 \%$, berada pada katagori sangat baik $(75 \%<\mathrm{NR} \leq 100 \%)$. Hasil wawancara dengan salah satu siswa mengatakan sangat senang belajar dengan menggunakan metode STAD karena siswa termotivasi dalam mengikuti pembelajaran, mampu menghargai perkerjaan orang lain, serta mampu berkerja sama dalam kelompok tidak membedakan antara yang pintar dengan yang lemah.

\section{Refleksi}

Pelaksanaan pembelajaran dengan menggunakan metode STAD dalam pembelajaran pendidikan agama hindu khususnya materi catur guru, dapat meningkatkan aktivitas belajar siswa. Hal ini diketahui dari hasil pelaksanaan pembelajaran siklus I ke pembelajaran siklus II, aktivitas belajar siswa semakin meningkat. Beberapa kelemahan yang menjadi refleksi dari pelaksanaan siklus I telah di perbaiki pada pelaksanaan siklus II, sehingga pelaksanaan pembelajaran dapat berhasil dengan baik. Untuk dapat mencapai aktivitas siswa yang $100 \%$, diperlukan aktivitas guru yang benarbenar sempurna dalam pengajaran.

\section{Penutup}

Berdasarkan hasil penelitian tindakan kelas yang telah dilaksanakan melalui penerapan model kooperatif tipe STAD pada pembelajaran Catur Guru di kelas V SDN 15 Dampelas, aktifitas belajar siswa dapat meningkat. Hal ini dapat dibuktikan dengan adanya peningkatan aktivitas belajar siswa pada setiap siklus penelitian tindakan kelas. Berdasarkan reflleksi dan hasil observasi aktivitas guru dan aktivitas siswa pada siklus I terdapat beberapa kelemahan yang menyebabkan hasil belajar siswa belum optimal sehingga dilanjutkan ke siklus II. Aktivitas belajar siswa dalam proses pembelajaran Catur Guru dengan menggunakan model kooperatif tipe STAD berjalan dengan baik, keaktifan siswa meningkat dalam bekerja sama menyelesaikan soal diskusi yang diberikan oleh guru. Persentase peningkatan aktivitas berlajar siswa dengan menerapkan metode STAD dalam pembelajaran pendidikan agama Hindu khususnya materi catur guru dapat dilihat pada tabel berikut. 
Tabel 8. Presentase Aktivitas Guru dan Siswa Persiklus

Hasil Observasi Aktivitas Guru dan Siswa

\begin{tabular}{|c|c|c|c|c|c|}
\hline \multicolumn{3}{|c|}{ Siklus I } & \multicolumn{3}{|c|}{ Siklus II } \\
\hline 1 & $\begin{array}{l}\text { Hasil observasi } \\
\text { aktivitas Guru }\end{array}$ & $\begin{array}{l}75,00 \% \\
\text { (baik) }\end{array}$ & 1. & $\begin{array}{l}\text { Hasil observasi aktivitas } \\
\text { Guru }\end{array}$ & $\begin{array}{l}95,83 \% \\
\text { (sangat baik) }\end{array}$ \\
\hline 2 & $\begin{array}{l}\text { Hasil observasi } \\
\text { aktivitas siswa }\end{array}$ & $\begin{array}{l}63,64 \% \\
\text { (baik) }\end{array}$ & 2. & $\begin{array}{l}\text { Hasil observasi aktivitas } \\
\text { siswa }\end{array}$ & $\begin{array}{l}91,91 \% \\
\text { (sangat baik) }\end{array}$ \\
\hline
\end{tabular}

Berdasarkan tabel di atas dapat

Keterampilan Berpikir, Edisi

diketahui bahwa Aktifitas guru meningkat

Keenam. Jakarta: PT. Indeks.

dari $75 \%$ menjadi 95,83\%, sehingga pada

siklus II sesuai dengan obserasi yang

dilakukan mengalami peningkatan sebesar 20,83\%. Sedangkan pencapaiaan aktivitas siswa pada saat mengikuti pembelajaran siklus I mencapai 63,64\%, meningkat menjadi 90,91\%. Peningkatan dari siklus I ke siklus II adalah sebesar 27,27\%. Pada siklus II aktivitas guru dan siswa berada dalam kriteria sangat baik dimana $75 \%<\mathrm{NR} \leq 100 \%$. Oleh karena itu penerapan metode STAD dalam pembelajaran pendidikan agama Hindu khususnya materi catur guru dapat meningkatkan aktivitas belajar siswa kelas V SDN Dampelas.

\section{Daftar Pustaka}

Calhoun, Emily, dkk 2011 Models Of Teaching, Model-Model Pengajaran, Edisi Delapan. Yogyakarta: Pustaka Pelajar.

Hamdani. 2011. Strategi Belajar Mengajar. Bandung: Pustaka Setia.

Miles, Matthew dan Huberman. 1992. Analisis Data Kualitatif (terjemahan). Sage Publications.Inc.

Purwanto, N.2010. Prinsip-Prinsip dan Teknik Evaluasi Pengajaran. Bandung: PT. Remaja Rosdakarya.

Sagala, Syaiful, 2004. Pembelajaran Kooperatif (Cooperatif learning). Bandung: PT. Remaja Rosdakarya.

Sardiman. 2005. Interaksi dan Motivasi Belajar Mengajar. Jakarta: PT. Raja grafindo persada

Siberman, Melvin. L. 2013. Active Learning: 101 Cara Belajar Siswa Aktif. Bandung: Nuansa Cendekia.

Somadayo, Samsu.2013. Penelitian Tindakan Kelas. Yogyakarta: Graha Ilmu.

Kauchak, Don \& Paul Eggen. 2012. Strategi dan Model Pembelajaran Mengajarkan Konten dan 
Suardi, Moh. 2012. Pengantar Pendidikan Teori dan Aplikasi. Jakarta: PT. Indeks.

Susilo, Herawati, dkk. 2012. Penelitian Tindakan Kelas Sebagai Sarana Pengembangan Keprofesionalan Guru dan Calon Guru. Malang: Bayu Media Publishing.

Trianto, 2010. Model Pembelajaran Terpadu. Jakarta: Bumi Aksara.

Uno, Hamzah B. 2006. Perencanaan Pembelajaran. Jakarta: PT. Bumi Aksara.

Winkel, W.S. 2012. Psikologi Pengajaran. Yogyakarta: Media Abadi. 